\title{
Fostering Employee Engagement through Human Resource Practices: A Case of Manufacturing Firms in Malaysia
}

\author{
(Mewujudkan Keterlibatan Pekerja Melalui Amalan Pengurusan Sumber Manusia: \\ Satu Kes Syarikat-syarikat Perkilangan di Malaysia)
}

\author{
Johanim Johari \\ Zurina Adnan \\ Tan Fee Yean \\ Khulida KiranaYahya \\ Site Nora Isa \\ (College of Business, Universiti Utara Malaysia)
}

ABSTRACT

The primary objective of this study is to determine the influence of human resource management (HRM) practices on employee engagement. HRM practices comprise of training and development, financial and non-financial recognition, fringe benefits, and supervisor-subordinate relationship. A total of 306 operational level employees in manufacturing firms in the Northern Region of Peninsular Malaysia reported on HRM practices in their respective organizations as well as their level of engagement at work. Statistical analyses were conducted to examine the influence of HRM practices on employee engagement. The findings reported a significant and positive impact of financial and non-financial recognition as well as fringe benefits on employee engagement. The regression analysis result indicated that 40 percent of total variance of employee engagement was explained by HRM practices dimensions. Discussions elaborated on the research results while implications brought to fore the theoretical and practical contributions of this study. Finally, recommendations addressed several directions for future research.

Keywords: Human resource management practice; employee engagement; Malaysia

ABSTRAK

Objektif utama kajian ini adalah untuk mengkaji pengaruh amalan pengurusan sumber manusia (PSM) terhadap keterlibatan pekerja. Amalan PSM terdiri daripada latihan dan pembangunan, pengiktirafan kewangan dan bukan kewangan, faedah sampingan, dan hubungan penyelia dengan pekerja. Sejumlah 306 pekerja peringkat operasi dalam syarikat perkilangan di kawasan Utara Semenanjung Malaysia telah menjawab soal-selidik mengenai amalan PSM dalam organisasi masing-masing serta tahap keterlibatan mereka di tempat kerja. Analisis statistik telah dijalankan untuk mengenal pasti pengaruh amalan PSM terhadap keterlibatan pekerja. Hasil kajian mendapati terdapat hubungan yang signifikan dan positif antara pengiktirafan kewangan dan bukan kewangan serta faedah sampingan dengan keterlibatan pekerja. Keputusan analisis regresi juga menunjukkan bahawa amalan PSM menjelaskan sebanyak 40 peratus varians dalam keterlibatan pekerja. Perbincangan memperjelaskan hasil kajian manakala implikasi menjelaskan sumbangan teoretikal dan praktikal kajian ini. Akhir sekali, cadangan kajian mengemukakan beberapa arah kajian untuk masa hadapan.

Kata kunci: Amalan pengurusan sumber manusia; keterlibatan pekerja; Malaysia

\section{INTRODUCTION}

To maximize profitability and achieve organizational goals, employers must be able to recruit, select, develop, and retain their employees. However, the challenge today is not just in acquiring and retaining people, but also in engaging employees by capturing their minds and hearts at each stage of their work lives (Kaye \& Jordan-Evans 2003). According to Richman (2006), engagement level among employees is on a serious declining stage as most of the employees nowadays are experiencing disengagement in their job and organization. Importantly, it has been reported that majority of employees today will not fully engage if they received less support, awards and recognitions from their respective employers (Bates 2004; Richman 2006). The disengagement among employees caused the engagement gap that could bring about undesirable organizational outcomes, such as customer dissatisfaction, low productivity, and unprofitability. If employees are disengaged, they will not be committed to their job and this will also limit their contribution to the organization, which in turn affects organizational performance. According to Bates (2004), employee disengagement has cost the US businesses $\$ 300$ billion a year in lost productivity. In addition, the results from a research by Towers Watson (2012) corroborated that organizations with high level of employee engagement levels yielded an average one year operating margin 
that is three times higher than those with lower level of employee engagement. The study further indicated that a 15 percent increase in employee engagement could result in two percent increase in operating margin and thus, boost the organizational profit (Towers Watson 2012). Hence, it can be summed up that employee engagement is the key business driver for organizational performance.

There are many benefits associated with high level of engagement among employees. It is reported that employee engagement could promote retention of talent, ensure excellent performance, foster customer loyalty, and improve organizational performance and stakeholders value (Lockwood 2007). Highly engaged employees feel a stronger bond with their respective organizations, which may result in a higher productivity level and lower turnover rate (Atkinson \& Frechette 2009). Employee engagement can also become a source of competitive advantage to an organization because engaged employees can help to achieve organizational mission, execute its strategy, and generate key business results (Vance 2006). Importantly, employee engagement is considered as the most powerful factor to measure companies' dynamism (Baumruk 2004).

Employee engagement can be fostered mainly through organizational support and practices. If employees perceive that resources are not available for them to perform their job, they become less engaged in work, which can lead to various undesirable workplace outcomes, including employee turnover (Schaufeli \& Bakker 2004). This usually happens when employees feel that their needs are not fulfilled, which may ultimately elicit some form of dissatisfactions and low level of commitment and motivation. It deserves noting that employer-related factors are the main drivers to positive and productive perception, attitude, and behaviors of employees at work On the same ground, Gubman (2004) and Robinson, Perryman and Hayday (2004) have coined employee engagement as "a positive attitude held by the employee towards the organization and its values". Reciprocally, organizations must also work toward inculcating and sustaining engagement among employees. In doing so, organizations have to adopt and maintain good systems and practices so that high level of engagement can be reinforced among employees over time.

Empirical evidences (e.g. Gubman 2004; Schaufeli \& Bakker 2004; Vance 2006) have emphasized on the crucial role of HRM practices in promoting high engagement level among employees. This is attributable to the fact that good HR practices embedded in organizational systems are likely to have a significant and positive impact on engagement level. For instance, Cherrington (1995) pointed out that if employees are happy and satisfied with the training programs and career advancement opportunities in their organization, they will be more motivated, committed, and engaged at work. Likewise, a study by Morgan (2004) also revealed that HR department is responsible for 40 percent of engagement program, including organizing effective training programs, offering attractive compensation and benefits package, providing systematic and efficient staffing practices, and adopting quality supervisory management. In light of the relevance of HRM functions in enhancing positive attitudinal outcomes at the workplace, this study attempts to assess the extent to which HRM practices exert positive influence on employee engagement. Specifically, HRM practices are assessed in terms of training and development, financial and nonfinancial recognition, fringe benefits, and supervisorsubordinate relationship.

\section{LITERATURE REVIEW}

\section{UNDERLYING CONCEPT OF EMPLOYEE ENGAGEMENT}

Employee engagement is a business management concept and there are many definitions of this particular construct. It was defined by Saks (2006) as a heightened connection between employees and their work, their organization, or the people they work for or with. Perrin (2009) conceptualized employee engagement as the degree to which employee's think, feel, and act in line with company's goals, which includes the extent to which employees go the extra mile in their work in the form of discretionary effort, creativity, and energy. Wellins, Bernthal and Phelps (2005) operationalized engagement as the extent to which people enjoy and believe in what they do and feel valued for doing it. The concept also focuses on the degree to which employees commit to something or someone in the organization, and how long they stay in the organization as a result of that commitment (Morgan 2004; Markos \& Sridevi 2010). Schaufeli and Bakker (2004) defined employee engagement as a positive, fulfilling, work-related state of mind that is characterized by vigor (i.e. feeling energetic and resilience at work), dedication (i.e. being proud of and happy about one's work) and absorption (i.e. being totally immersed in one's work). According to Saks (2006), employee engagement consists of two dimensions, which are cognitive or intellectual and emotional. Cognitive engagement is where employees are sure about their job requirements and role expectations. Emotional engagement means that employees receive timely feedback and engage in social interactions with their co-workers, which make them feel connected to their organizational members (Saks 2006). Similarly, Baumruk (2004), Richman (2006), and Shaw (2005) defined employee engagement as emotional and intellectual commitment to organization.

In a broader term, Kahn (1990) defined employee engagement as the harnessing of organization members' selves to their work roles, whereby highly engaged employees express themselves physically, cognitively, and emotionally in performing their roles at work. The cognitive aspect of employee engagement concerns employees' beliefs about the organization, its leader, and working conditions. The emotional aspect concerns how employees feel about each of the three factors and 
whether they have positive or negative attitude towards the organization and its leaders. The physical aspect of employee engagement concerns the physical energies exerted by individuals to accomplish their roles. According to Kahn (1990), engagement means that employees are being psychologically as well as physically present when occupying and performing an organizational role. Frank, Finnegan, and Taylor (2004) expanded the concept of employee engagement by incorporating the amount of discretionary effort demonstrated by employees in their jobs. The broader concept of engagement by Frank et al. (2004) also includes the elements of sincerity in employees and their level of focus at work. In a parallel fashion, Truss et al. (2006) defined employee engagement as a 'passion for work' or a psychological state, which is seen to encompass the three dimensions of engagement as earlier discussed by Kahn (1990). Overall, the various definitions have given an in-depth understanding on the concept of employee engagement. Given the importance of employee engagement concept in the literature, more studies need to be conducted to further scrutinize this particular construct and understand factors attributed to it.

\section{HRM PRACTICES}

Guest and Peccei (2001) operationalized human resource management as a unitary system of management that attempts to elicit employees' commitment and involvement in line with the purpose and goals of the organization. Human resource has also been defined as a strategic and coherent approach to the management of an organization's most valued assets because it involves managing people in organization to achieve its objectives (Mondy 2011). HRM is also perceived as the science and practice that deal with the nature of the employment relationship and all of the decisions, actions, and issues that are related to the relationship (Ferris et al. 1999). Mondy (2011) asserted that a comprehensive model of human resource practices should incorporate the elements of workers' ability and work engagement. According to Storey (1995), human resource management involves top management and line management in practicing the principle, which makes business personnel capable and committed to endow with a competitive advantage.

Storey (1995) provided a more holistic perspective of HRM practices by introducing the soft and hard dimensions of the construct. The former aspect includes culture in which employees are considered as a source of vigor and all employees fully participate in decisionmaking, particularly those that focuses on long-term profitability. By being empowered, employees would create a sense of belonging towards their organizations, which can enhance desirable attitude and behavior at work. Hard HRM dimension, on the other hand, delves into the culture that emphasizes on the arrangement of the structure and strategy, which are more focused on organizational control, carefulness, and profitability (Storey 1995). A more sophisticated role of HRM practices was developed by Becton and Schraeder (2009), who mentioned that the implementation of strategic human resource management strengthens the status of this function in an organization through the formulation and development of employee skills. This shows that human resource practices play an important strategic role in promoting various positive outcomes at the employee and organizational levels.

In the Malaysian context, studies on the predicting role of HRM practices have been done extensively. However, in most instances, these studies (Sanjeevkumar 2012; Shamsudin et al. 2011; Subramaniam et al. 2011) focused on various other dimensions of HRM practices, such as job security, information sharing, and work-life balance. According to Mondy (2011) and Comm and Mathaisel (2003), HRM practices dimensions, particularly training and development, compensation and benefits, and superior-subordinate relationship are very important in enhancing employees' motivation, commitment, satisfaction as well as other attitudinal outcomes. The reason is attributed to the fact that compensation, be it financial or non-financial, can be a powerful tool in encouraging an individual employee to work harder by getting highly engaged and committed in his or her work. On a similar ground, superior and subordinates can help employees keep abreast with their performance and expectations from time to time. Therefore, through quality communication and relationship with supervisor, employees are aware of their strengths and weaknesses and from there, they are able take necessary actions to improve and enhance their competency and work performance. Further, training and development programs are necessary for employees to develop their knowledge, skills, and abilities for undertaking more challenging tasks which may be the requirement for future career positions. With sufficient knowledge and skills gained through training and development programs provided by their respective employer, employees are more engaged and committed at work and are able to demonstrate outstanding quality of work. Accordingly, studies by Aggarwal, Datta, and Bhargava (2007), Minbaeva (2008) and Sardar et al. (2011) also reported that compensation and benefits, including financial and non-financial rewards, training and development, and good supervisor-subordinate relationships as the most important source for organizations to generate a pool of motivated, competence and high performing employees, who can significantly contribute towards developing organizational competitive advantage. In other words, these dimensions of HRM were found to have a stronger predicting role in unveiling various employees' attitudinal as well as behavioral outcomes. Drawing on the empirical assertions, four dimensions of HRM practices (i.e. training and development, financial and non-financial recognitions, fringe benefits, and supervisor-subordinate relationship)are incorporated as the independent factors in determining the engagement level among employees in this study. 


\section{TRAINING AND DEVELOPMENT}

Training and development is one of the important human resource management practices. This aspect of HRM practice is always referred to as a tool to improve current skills or to acquire new skills. Training and development also focus on changing or improving the knowledge, attitude, and behavior of individuals (Werner \& DeSimone 2009). According to Mondy (2011), training put emphasis on the learning of skills, knowledge, and attitudes required to initially perform a job or task or to improve upon the performance of a current job or task, while development activities concentrate on broadening the employee's horizons, and offering limitless career advancement opportunities. In other words, training prepares employees for a new job while development is essential for future assignment. Development has also been defined as an act or process of developing of the individual in terms of ability, understanding and awareness in the long-run (Werner \& Desimone 2009). Besides knowledge, skills, attitude, and behaviors, training aims to increase abilities in relation to potential position or job in the near future (Dowling \& Welch 2004). According to Werner and Desimone (2009), effective training will not only equip employees with most of the knowledge and skills needed to accomplish jobs but it would also help to achieve overall organizational objectives by enhancing the satisfaction and productivity level among employees. On the contrary, development is considered as an act or process of developing individuals in terms of ability, understanding, and awareness (Chen et al. 2004). Development opportunities also prepare employees for other positions which may be available in the future. Most importantly, training and development function allows organizations to align the development of competencies of its work force by taking into account the strategic goals of organization (Chen et al. 2004). Despite different meanings of these two concepts, both are closely related to each other in improving and enhancing employee knowledge, skill, abilities, attitude, and behavior at work.

Training and development have brought about numerous advantages to individuals as well as organizations. Among others are reduced learning time for new hires and current employees, decreased in the number and cost of accidents, better customer-service, and improved quality and quantity of productivity (Cherrington 1995). Management should ensure that continuous training is given out to all employees in order to achieve future goals. According to Chen et al. (2004), training may help employees to reduce their anxiety of frustration due to various work demands that they are not familiar with and lack of skills in performing it. Employees are more confident to execute their job or task when they feel their skills have substantially improved resulting from training received. Accordingly, Barton and Delbridgde (2001) noted that training is the systematic development of the attitude, knowledge, and skills pattern that are required by a person to perform a given task or job adequately. In order to ensure the employees' skills are upgraded from time to time, continuous training and development of the workforce is of utmost important. Bohlander and Snell (2013) indicated that training is indispensable for the success and productivity as it heightens up employee performance.

The findings by Chang and Chen (2002) showed a positive and significant relationship between training and employees productivity. Cherrington (1995) asserted that training and development are the important factor in promoting employee engagement. In the same vein, Sardar et al. (2011) concurred that training improves service inaccuracy and it can at once impact service performance and employee engagement, which ultimately improve employee performance. Bohlander and Snell (2013) pointed out that training and development are important drivers for sustaining engagement level. Besides improving knowledge, skills, and abilities, training and development programs provided could help employees build up confidence in performing their jobs. Being confident and able to do their best at work inculcate various other positive attitudinal and behavioral outcomes. A study conducted by Lim and Ling (2012) unveiled that employees' work attitudes are influenced by the perception on the extent to which their employers are making effort to provide effective training and development programs for them. From the employees' perspective, training and development is an important tool to gain valuable support, knowledge, skills and abilities that may enhance their opportunities for career advancement and job security in their respective employment. Thus, adequate training and development opportunities play an important role in determining employees' engagement. As such, it is hypothesized that:

$\mathrm{H}_{1} \quad$ Training and development have a positive and significant influence on employee engagement.

\section{RECOGNITION}

According to London and Higgot (1997), employee recognition is a timely, informal or formal acknowledgement of a person's or team's behavior, effort or business result that supports the organization's goal and values that are beyond normal expectations. Reward and recognition for individual employees remain as one of the crucial areas in HRM practices (London \& Higgott 1997). This is because recognition and reward are part of the compensation package that has been used to attract, motivate, and retain employees. Many organizations do not solely capitalize on recognition and reward to retain employees, but also to use it as a strategic tool to promote good work attitude among employees, such as commitment and engagement (Lim \& Ling 2012; Snape \& Redman 2010). Importantly, recognition serves as a form of feedback where it helps to inform employees about their performance level. Latham and Ernst (2006) asserted that in order to create ongoing motivation and commitment through employee recognition, reward must be well-communicated to all employees. Employee reward and recognition programs are 
one of the most practical method of motivating employees to demonstrate functional work habits for the benefits of the organization. A study by Deilman et al. (2003) found that recognition and respect from managers and colleagues are among the motivating factors for healthcare workers. Employees, who feel appreciated, are more positive about their ability to contribute towards company's goals and objectives. In a similar fashion, Herzberg's (1959) two-factor theory proposed that recognition is among the factors that could increase employee's intrinsic willingness to engage in work (Herzberg 1959; Latham \& Ernst 2006). Recognition has been reported to be effective in increasing productivity, profits, and customer satisfaction (Snape \& Redman 2010). It is evident that recognition plays a vital role in supporting organization to achieve the setting goals and objectives. Accordingly, employees would feel motivated to put out more efforts toward organizational objectives. This also promotes various positive attitudinal and behavioral outcomes, including employee engagement.

There are two basic types of rewards, financial and non-financial, which can be utilized to enhance positive behaviors of employees (Latham \& Ernst 2006). The finding by Rose (1998) indicates that there was a significant and positive relationship between recognition and employee performance. This is because employee will show a better performance when they feel satisfied and motivated. In other words, recognition, be it financial or non-financial, that employees receive from time to time, will help to improve their performance at a higher level. In essence, people who feel appreciated are more positive about themselves and their ability to contribute because recognition changes and reinforces a culture that focuses on both people and productivity (Latham \& Ernst 2006). Therefore, awareness from organization is crucial in providing recognition that will drive employees to work towards the targeted results. According to Dielman et al. (2003), recognition and respect from managers and colleagues are among the most crucial drivers to promote the feeling of being valued and appreciated within employees. In other words, both financial and non-financial recognitions are the catalysts to produce good employee's attitude and behavior at work. Therefore, this study theorizes that financial and non-financial recognitions exert positive impact on employee engagement.

\section{FINANCIAL RECOGNITION}

Floyd and Wooldridge (1994) defined financial recognition as the monetary rewards given to employees as a source of encouragement and commitment towards achieving organization's goal and performance objective. Financial recognition was found to be the most important source of reward to attract, motivate, and retain employees (Blegen et al. 1992). Omolayo and Owolabi (2007) asserted that financial recognition is very vital, especially for the lower-positioned employees, because this group of employees place higher value on financial compensation in order to make ends meet. As such, inadequate financial recognition is considered as a major setback for employees' commitment, which is normally reflected in a high level of absenteeism and tardiness, low performance, grievances, and increased employee turnover rate (Omolayo \& Owolabi 2007). Similarly, Gratton (2004) concurred that even though motivation is determined by monetary and non-monetary rewards, financial factor plays a more substantialrole in determining employees' behaviors. A study by Omolayo and Owolabi (2007) revealed that financial recognition is a yardstick in determining the level of employees' commitment in almost any organizations. Based on all the empirical results, it is evident that financial recognition is an important predictor in elevating positive attitudinal and behavioral outcomes, including engagement level, among employees. Therefore, this study posits that:

$\mathrm{H}_{2}$ Financial recognition has a positive and significant influence on employee engagement.

\section{NON-FINANCIAL RECOGNITION}

Non-financial recognition is defined as a non-monetary reward to motivate and to help develop feelings of confidence and satisfaction among employees (Keller 1999). Silverman (2004) mentioned that the most significant part of this definition concerns the term of 'non-monetary'. Non-financial recognition is a method of repaying individual or team achievement through various types of acknowledgement (Silverman 2004). Examples of non-financial recognitions are job enlargement, job advancement, flexible work hours, and also praises by superior for good work. Rose (1998) asserted that non-financial recognition is a non-cash award given in acknowledging high level of accomplishment or performance, which is not contingent upon the achievement of pre-determined target.

Many organizations are beginning to realize that the ability to provide competitive compensation package is very much determined by the portion offered in relation to non-financial factors. Silverman (2004) noted that non-financial recognition schemes can help fulfill organizational objectives at a relatively low cost. This is because organizations can revise, improve, reorganize, or increase their non-financial recognition any time even during recession period. This is due to the fact that nonfinancial recognition incurs a very low cost as in most cases this form of recognitions do not involve financial costs at all. Unfortunately, Gratton (2004) stated that most companies spend very limited time and effort on formulating non-monetary reward program as a source of motivation even though this aspect of compensation package was reported to have a substantial impact on firms' ability to attract, motivate, and retain employees (Silverman 2004). In fact, a study by Brown and Armstrong (1999) also revealed that approximately 50 percent of the UK organizations used non-financial recognition scheme to 
motivate employees. Bevan's (2003) study echoed similar findings that more than 60 percent of UK employers use non-financial recognition to improve motivation and commitment level among employees. In a similar vein, Brown and Armstrong (1999) stated that organizations are overhauling their non-financial recognition scheme so that there is a much clearer focus on strategic business goals and values, such as team work, customer service, and business improvement. When organizations reorganize their non-financial recognition to be more competitive, it will enhance the satisfaction towards organization and desirable results can be seen through good team work, higher customer service quality, and greater business improvement. Empirical evidences highlighted earlier have lent support for the notion that organizations can rely on non-financial recognition to promote positive attitude and behavior at work, including employee engagement. As such, it is hypothesized that:

$\mathrm{H}_{3}$ Non-financial recognition has a positive and significant influence on employee engagement.

\section{FRINGE BENEFITS}

Fringe benefits are also referred to as perquisites, perks, or any other form of compensation given to employees, such as company car, house allowance, medical insurance, paid holidays, pension schemes, subsidized meals and many more, in addition to basic wages or salary (Bohlander \& Snell 2013). Fringe benefits are becoming increasingly popular as a part of firms' compensation schemes. Besides salary and financial rewards, employees are looking for an attractive benefits package offered by organizations. Organizations that provide good benefits will have an added advantage in terms of promoting positive attitude and behavior among employees. Empirical findings (DaleOlson 2006; Wilkinson 2007) demonstrated that fringe benefit have a stronger influence on turnover reduction because employees who are happy and satisfied with benefits offered are less likely to leave their organization. According to Bohlander and Snell (2013), in the absence of salary rises and cash bonuses, fringe benefits can reconcile frustrated employees and encourage loyalty in the long run. In other words, competitive fringe benefits could help organizations to retain employees and minimize staffing costs, such as recruitment and selection of new candidates. Wilkinson (2007) reported in his study that fringe benefits have a direct influence on employee attitudinal outcomes, such as commitment and engagement. As posited by Gottlied (2011), fringe benefits have many advantages for employers because when employees truly understand and enjoy their benefits, they will more satisfied and loyal to their employers. On this note, attractive fringe benefits will encourage long-term employee loyalty and improve employee performance as well as engagement (DaleOlson 2006). In essence, employees who understand and satisfied with the benefits offered will remain motivated and engaged in their present employment because they feel the benefits offered have fulfilled and accommodated their self needs. Based on all the empirical findings, it is evident that attractive fringe benefits package contributes significantly towards positive workplace outcomes. Therefore, this study posits that:

$\mathrm{H}_{4}$ Fringe benefits have a positive and significant impact on employee engagement.

\section{SUPERVISOR-SUBORDINATE RELATIONSHIP}

Supervisor is an individual in the first-line management who monitors and regulates employees in their performance of assigned or delegated tasks. Supervisors are usually authorized to recommend employment and promotion of their subordinates. Hence, their decision would affect the hiring, disciplining, promoting, punishing, rewarding and other associated activities of subordinates under their supervision (Burke 2011).

According to Burke (2010) and Perrin (2009), there are several key drivers to employee engagement and one of the factors is quality supervisor-subordinate relationship. They further added that supervisors who always cultivate positive and caring relationships with their subordinates are more likely to garner a high level of engagement among employees. In other words, supervisors also play a strategic role in fostering employee engagement. Wagner and Harter (2006) theorized that immediate supervisors have the strongest influence on employee engagement. This is in accordance to a study by Swindall (2007), which re-affirms that employees do not leave organizations, instead they leave bosses and this will incur losses to the organization, resulting from dissatisfactions that employee have with their immediate supervisors. McPhie et al. (2008) reported that one of the important elements in engaging employees is the satisfaction level with supervisors. Besides monitoring, supervisors also act as a medium of information between employees and the organization. They are the ones who deliver information from the management group and acquire feedback from employees. When supervisors develop healthy supervisor-subordinate relationship in monitoring and dealing with their subordinates, employees are satisfied and happy at their workplace. This would result in desirable workplace outcomes in terms of cognitive, affective, as well as behavior. Having said so, this study hypothesizes that:

$\mathrm{H}_{5}$ Supervisor-subordinate relationship has a significant and positive impact on employee engagement.

Past researchers (Doherty 2010; Bhatnagar 2007; Saks 2006; Shuck et al. 2011; Tomlinson 2010) have agreed that HRM practices are the significant antecedent to employee engagement. This assertion aligns with the basic assumptions in the Social Exchange Theory (SET). SET is a social psychological perspective, which purports that all forms of human relationships within an organization are established through an exchange process between two 


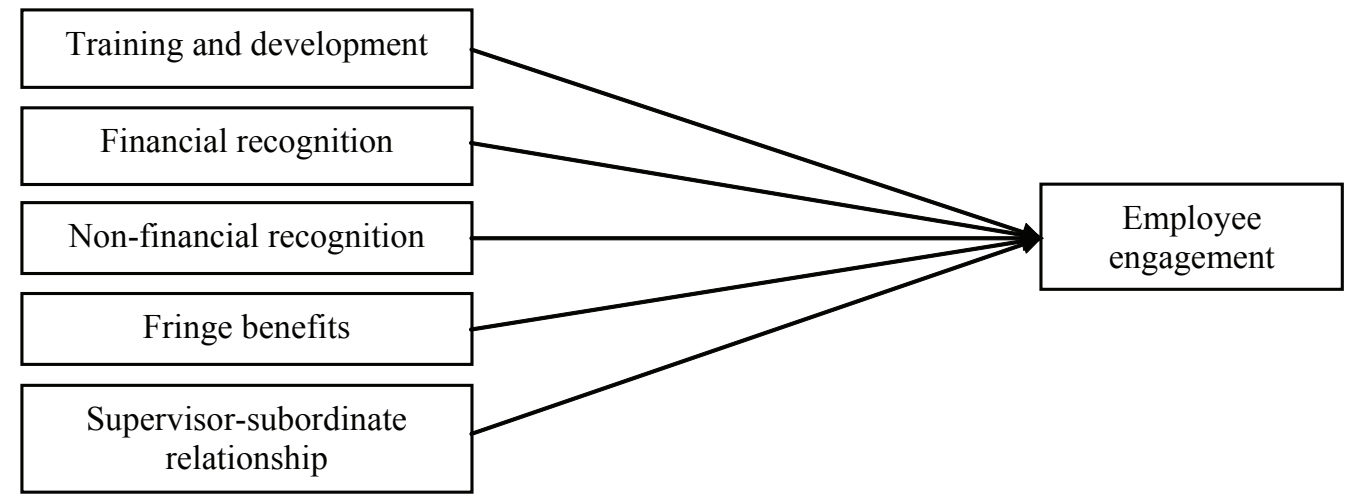

FIGURE 1. Research framework

parties, i.e. employers and employees (Emerson 1976). Generally, SET is developed to describe how individuals respond to the contextual or environmental situations, in terms of pay, work environment, etc., provided by employers as a return of their employees' actions and behaviors at workplace. One of the important assumptions of SET is that workplace behaviors (i.e. employees' engagement) are influenced by aspects that are related to individuals (interpersonal relationship) and organizations (e.g. HRM practices) (Cropanzano \& Mitchell 2005; Emerson 1976).

In essence, SET proposes that reciprocal relationships are nurtured between superiors and employees, when the latter has positive perceptions toward the rewards received. This, in turn, will encourage employees to engage in a more positive outcome, such as high level of engagement (Cropanzano \& Mitchell 2005). This suggests that employees will instill beliefs based on their observation and perceptions toward the extent to which their superiors will appreciate their job efforts and contribution. Therefore, employees' perception can serve as the indicator of their levels of satisfaction and engagement, in which employees become attached to their organization when they perceive that there is a beneficial exchange relationship exists between them and their organizations. Furthermore, employee engagement can also be increased if employees are satisfied with the returns (i.e. equitable compensation systems and effective training and career development programs) provided by their respective employers. Building upon the results in past researches as well as theoretical propositions in SET, this study aims to examine the influence HRM practices (i.e. training and development, financial and non-financial recognitions, fringe benefits, supervisor-subordinate relationship) on employee engagement.

\section{METHODOLOGY}

\section{SAMPLE AND MEASURES}

This study used a quantitative approach to measure the relationship between HRM practices and employee engagement. The study focused on the manufacturing sector in Malaysia, given the fact that this sector is one of the main contributors to the nation's gross domestic product (GDP). Specifically, the manufacturing sector accounted for one third or 31.4 percent to the GDP (Economic Planning Unit 2010). Importantly, manufacturing industry in the nation has recorded an average annual turnover of 18.84 percent for time period of July 2010 to June 2011 (Federation of Malaysian Manufacturers 2011). This indicated that there is a need to examine the predicting role of HRM practices on engagement level among manufacturing employees in this study.

Population for this study includes all operational level employees (i.e. production operator, trainer, assistant team leader, and team leader) from manufacturing companies located in the Northern Region of Peninsular Malaysia. In the initial stage of data collection, a letter asking for permission to conduct a survey was sent to each Human Resource Department of the manufacturing companies in the aforesaid geographical area. Only five companies responded and indicated their willingness to participate in the survey. However, since the exact number of operational level employees from each of the companies understudy was not known (due to undisclosed data by the participated companies), the rule of thumb suggested by Roscoe (1975) as indicated in Sekaran (2003) were used. He proposed that sample size larger than 30 and less than 500 are appropriate, but sample size should be several times (i.e. preferably 10 times or more) as large as the number of variables in the multivariate analyses. As the manufacturing employers were not willing to reveal the total number of operational level employees in their respective companies, the proportionate sampling technique could not be conducted. Hence, it was decided that all participating companies will be given an equal number of questionnaires. This means that 100 set of surveys was given out to each of the respective company. Thus, a total of 500 set of questionnaires were distributed. Out of 500 questionnaires distributed, only 306 questionnaires were returned and usable for further analysis, which constitute of 61.2 percent response rate.

Respondents were asked to rate their answers on a five-point Likert scale, from 1 (strongly disagree) to 5 (strongly agree). Employee engagement items were 
designed to gauge respondents' emotional engagement to their job, colleagues and organization (Scarlett 2009). As for HRM Practices, training and development dimension was measured by five items adapted from Hackman and Oldham (1975) and Al-Khayyat and Mahmoud (1997). Financial recognition construct was assessed by seven items adapted from pay raises and pay structure/administration subscales of the Pay Satisfaction Questionnaire (PSQ) by Heneman and Schwab (1985). Non-financial recognition items were adapted from recognition subscale of Minnesota Satisfaction Questionnaire (MSQ) (Weiss et al. 1967) and this dimension was measured by 10 items.

Fringe benefits instrument was adapted from Employment Benefits Satisfaction Questionnaire developed by Lawler (1971) and Luceru (1991). Finally, supervisor-subordinate relationship was measured by nine items adapted from The Supervisory Relationship Questionnaire (SRQ) developed by Palomo (2004).

\section{DATA ANALYSIS}

Reliability test was conducted by observing the values of Cronbach's Alpha for all variables of interest in this study. Subsequently, multiple regression analysis was conducted to examine the influence of training and development, financial and non-financial recognition, fringe benefits and supervisor-subordinate relationship on employee engagement among operational level employees in this study.

\section{FINDINGS}

\section{DEMOGRAPHIC PROFILES OF THE RESPONDENTS}

The respondents consisted of $201(65.7 \%)$ male and $105(34.3 \%)$ female. The demographic result showed that 71 respondents were below 25 years old and 63 of them were in the age group of 25 to 29 years old. The majority of respondents (299) were Malays and a total of 183 were married. The result revealed that the vast majority $(71.9 \%)$ of the respondents were SPM or highschool diploma holders. A total of $73(23.9 \%)$ respondents had been working in their present company for less than two years while 58 (19\%) of respondents had served in their respective company for six to nine years. As for organizational tenure, $64(20.9 \%)$ of respondents had been employed in the present company for 10 to 13 years. In terms of position, $214(69.9 \%)$ were production operators, $45(14.7 \%)$ were trainers while the rest were assistant team leaders and team leaders. As far as income is concerned, 220 respondents received monthly pay less than RM800.00 while only 7 percent of the respondents received income more than RM1401.00.

\section{DESCRIPTIVE STATISTICAL RESULTS}

Table 1 shows the reliability results, means and standard deviation of the variables. Overall, the values of Cronbach's alphas were all above the acceptable limit of 0.70 . It is interesting to note that respondents in this study reported a high level of engagement with the mean value 3.62 . Respondents also experienced effective HRM practices in their respective organizations with the mean values of training and development, financial recognition, and nonfinancial recognition of $3.59,3.46$, and 3.57 , respectively. Two other dimensions of HRM practices showed relatively low mean values of 3.21 for fringe benefits and 3.31 for supervisor-subordinate relationship.

TABLE 1. Reliability, means and standard deviation of variables

\begin{tabular}{lccc}
\hline \multicolumn{1}{c}{ Items } & $\alpha$ & Mean & Std. Deviation \\
\hline Training and development & 0.860 & 3.59 & 0.67 \\
Financial recognition & 0.734 & 3.46 & 0.55 \\
Non-financial recognition & 0.808 & 3.57 & 0.51 \\
Fringe benefits & 0.787 & 3.31 & 0.65 \\
Supervisor-subordinate & 0.764 & 3.21 & 0.49 \\
$\quad \begin{array}{l}\text { relationship } \\
\text { Employee engagement }\end{array}$ & 0.758 & 3.62 & 0.55 \\
\hline
\end{tabular}

Notes: $\mathrm{N}=306 ; \alpha=$ alpha results, $\mathrm{M}=$ mean, $\mathrm{SD}=$ standard deviation

The regression analysis was conducted to determine the influence of HRM practices on employee engagement. The results indicated that financial recognition $(\beta=$ $0.206, \mathrm{p}<0.01)$, non-financial recognition $(\beta=0.233$, $\mathrm{p}<0.01)$, and fringe benefits $(\beta=0.245, \mathrm{p}<0.01)$ were the significant predictors of employee engagement. However, training and development and supervisorsubordinate relationship were found to have a nonsignificant impact on employee engagement with beta value of $0.028(p>0.01)$ and $0.050(p>0.01)$, respectively. Hence, only H2, H3, and H4 were supported.

The regression analysis also yielded $\mathrm{R}^{2}$ value of 0.40 , indicating that 40 percent of the variance that explained employee engagement was accounted for by dimensions in HRM practices, specifically training and development, financial and non-financial recognition, fringe benefits, and supervisor-subordinate relationship.

\section{DISCUSSIONS}

To recapitulate, the primary objective of this study was to assess the predicting role of HRM practices on engagement level among operational level employees. HRM practices consisted of training and development, financial and non-financial recognition, fringe benefits, and supervisor-subordinate relationship.

Training and development were found to be a nonsignificant factor in exerting employee engagement in this particular study. The result was inconsistent to findings in previous studies (e.g. Chang \& Chen 2002; Cherrington 1995; Keaveney 1995) that showed positive and significant influence of training and development on employees' attitudinal outcomes, such as commitment 
TABLE 2. Regression result of HRM practices and employee engagement

\begin{tabular}{|c|c|c|c|c|c|}
\hline & \multicolumn{2}{|c|}{$\begin{array}{l}\text { Unstandardized } \\
\text { Coefficients }\end{array}$} & \multirow{2}{*}{$\begin{array}{c}\text { Standardized } \\
\text { Coefficients } \\
\text { Beta }\end{array}$} & \multirow[b]{2}{*}{$\mathrm{t}$} & \multirow[b]{2}{*}{ Sig } \\
\hline & B & Std. Error & & & \\
\hline (Constant) & 1.095 & .197 & & 5.547 & .000 \\
\hline Training and development & .041 & .050 & .050 & .816 & .415 \\
\hline Financial recognition & .204 & .061 & $.206^{* *}$ & 3.329 & .001 \\
\hline Non-financial recognition & .251 & .069 & $.233 * *$ & 3.657 & .000 \\
\hline Fringe benefit & .205 & .054 & $.245^{* *}$ & 3.772 & .000 \\
\hline Supervisor-subordinate relationship & .032 & .069 & .028 & .463 & .643 \\
\hline
\end{tabular}

and motivation. One plausible explanation for this is attributable to the demographic factor of the respondents, who were mostly operational level employees. The skills and knowledge needed to perform jobs at this level requires minimal training because the jobs are generic in nature. Another most likely reason is that basic trainings received are considered sufficient for employees at the operational level to perform the required tasks. Also perhaps, training received during their previous employment may be adequate to master certain skills needed in their present jobs. Therefore, operational level employees might not look forward for additional training and development programs because the skills and knowledge they have were considered enough. As such, the training and development aspect in HRM practices had no bearing on their level of engagement at work.

The regression results revealed a positive and significant empirical link between financial recognition and employee engagement. This is consistent to the findings by Omolayo and Owolabi (2007) that employees, especially those in the lower-level position, placed a greater importance on financial recognition over other types of recognition. Financial recognition helps them to fulfill their basic needs, and without having the lowest level needs being fulfilled, positive outcomes in terms of cognitive, attitudinal as well as behaviors would hardly be inculcated within employees. This suggests that in fostering high level of engagement among employees, management should not overlook the importance of financial recognition. In fact, this aspect should be reviewed and improved from time to time in order to sustain employee engagement in organizations.

The regression analysis also elicited a substantial impact of non-financial recognition on employee engagement. In fact, this factor was the strongest predictor of engagement level among operational level employees in this study. The results lent support on the importance of non-financial recognition, which are also in agreement with the findings by Brown and Armstrong (1999) and Silverman (2004). This means that employees did not only look for financial recognition, but they also perceived non-financial recognition as a crucial aspect in guaranteeing their engagement at work. Whilst financial recognition fulfills their basic physical needs, non- financial recognition, such as praises from supervisors, help produce positive vibes within themselves. As such, desirable and productive outcomes, in terms of affective and behavioral, would transpire among employees at the workplace. Given the crucial role of non-financial recognition, this aspect deserves greater attention from the management in developing comprehensive and competitive compensation package in organizations.

The results of this study reported that fringe benefits exerted positive and significant influence on employee engagement. Evidently, this aspect of compensation and benefits determined the engagement level among operational level employees in this particular study. This circumstance also holds true in a study by Dale-Olson (2006), which reported that attractive fringe benefits offered would have an inverse influence on turnover intention. This suggests that if employees are not satisfied with the fringe benefits offered by their employers, they are more likely to be less committed. This would have detrimental effect on their decision to stay with their present employers. As such, employees who experienced dissatisfaction will seek employment opportunities elsewhere, particularly in organizations that offer a more attractive fringe benefits package. Therefore, organizations should put a more serious focus in designing competitive fringe benefits package so that high level of engagement prevails in the workforce.

Even though past researchers (Wagner \& Harter 2006; Swindall 2007; McPhie 2008) showed that supervisor-subordinate relationship has a strong influence on employee engagement, the notion did not stand true in this particular study. This indicates that supervisor-subordinate relationship had no significant impact on engagement level among employees. Despite the substantial role that supervisors have in monitoring employees' performance, this did not seem to determine their subordinates' level of engagement at work. In fact, employees in this study were very much driven by other factors that can fulfill their needs, such as financial and non-financial-rewards. One plausible explanation for this is because the job nature for employees at the operational level, whereby tasks were executed based on instructions given by their supervisors. They have limited autonomy to make decisions in performing their work. With clear 
directions from their supervisors, operational level employees were able to perform their jobs effectively. Thus, they do not have to establish good relationship with their supervisors in order to be highly engaged at work. In other words, in promoting engagement among employees, supervisor-subordinate relationship dimension should be given least attention in comparison to other factors examined in this study.

\section{IMPLICATIONS AND CONCLUSION}

The findings of this study have managed to provide theoretical as well practical ramifications. Based on the literature, Social Exchange Theory (SET) has been used widely in understanding how various contextual and personal factors (Aguilar \& Salanova 2005; Corace 2007) that influence employees' attitudes. However, limited research has been carried out, particularly on the influence of HRM practices on employee engagement that adopted SET as the foundation theory. As such, in terms of theoretical ramification, this study has to some extent contributed to the knowledge in this field of research. In other words, this study has given additional empirical evidence in the growing body of literature on employee engagement and SET from the Malaysian perspective.

In terms of practical contribution, the research results validated the notion that financial and non-financial recognition as well as fringe benefits is of utmost importance in promoting high level of engagement. Practically put, in assessing the strategic role of all HR functions, the aforesaid factors deserve a higher level of scrutiny in organizations. The role of HR as a strategic partner should also be given serious attention to ensure high level of engagement among employees.

This study has also paved several directions for future research. First, the future research should extend the sample to a bigger population, such as managerial level employees. Second, the framework of the study should be expanded by incorporating other HR practices, such as career development, performance appraisal and achievement, and so forth. Third, a comparative study between employees of different industries and levels or positions could provide a more detailed understanding on the relationship between HR practices and employee engagement. As a conclusion, the research results have provided support for the key theoretical proposition. Most importantly, this study has succeeded in answering all of the research objectives, which aimed at analyzing the empirical link between HR practices (i.e. training and development, financial and non-financial recognition, fringe benefits, and supervisor-subordinate relationship) and employee engagement.

\section{REFERENCES}

Aggarwal, U., Datta, S., \& Bhargava, S. 2007. The relationship between human resource practices, psychological contract and employee engagement: Implications for managing talent. IIMB Management Review 15(2): 313-325.
Aguilar, A. \& Salanova, M. 2005. Leadership Style and Its Relationship with Subordinate Well-Being (manuscript submitted for publication).

Al-Khayyat, R. M. \& Mahmoud, A. E. 1997. A macro model of training and development: Validation. Journal of European Industrial Training 21(3): 87-101.

Atkinson, T. \& Frechette, H. 2009. Creating a positive organizational climate in a negative economic on improving organizational climate to transform performance, Forum Transforming Performance.

Bates, S. 2004. Getting engaged. HR Magazine 49(2): 44-51.

Barton, H. \& Delbridge, R. 2001. Human resource management for the learning factory. Journal of European Industrial Training 25(9): 465-473.

Baumruk, R. 2004. The missing link: The role of employee engagement in business success. Workspan 47: 48-52.

Becton, J. \& Shraeder, M. 2009. Strategic human resources management: Are we there yet? The Journal for Quality and Participation 31(4): 11-18.

Bevan, S. 2003. Non-pay reward and recognition.Presentation for the Work Foundation, August.

Bhatnagar, J. 2007. Talent management strategy of employee engagement in Indian ITES employees: Key to retention. Employee Relations 29(6): 640-663.

Blegen M., Goode C., Johnson M., Maas M., McCloskey J. \& Moorhead, S. 1992. Recognizing staff nurse job performance and achievements. Research in Nursing and Health 15: 57-66.

Bohlander, G. W. \& Snell, S. 2013. Principles of Human Resource Management. $16^{\text {th }}$ edition. South-Western: Cengage Learning.

Brown, D. \& Armstrong, M. 1999. Paying for Contribution: Real Performance-Related Pay Strategies. London: Konan Page.

Burke, B. 2010. Supervisors are the key to high employee engagement and customer loyalty. Available at http:// www.humanresourcesiq.com/default/contributors/898barbara-burke

Chang, P. L. \& Chen, W. L. 2002. The effect of human resource management practices on firm performance: Empirical evidence from high-tech firms in Taiwan. International Journal of Management 19(4): 622-631.

Chen, I., Pauraj, A. \& Lado, A. A. 2004. Strategic purchasing, supply management, and firm performance. Journal of Operations Management 22: 505-523.

Cherrington, D. J. 1995. The Management of Human Resources. Englewood Cliffs, N. J.: Prentice Hall.

Comm, C. L. \& Mathaisel, D. F. X. 2003. A case study of the implications of faculty workload and compensation for improving academic quality.The International Journal of Educational Management 17(4/5): 200-10.

Corace, C. J. 2007.Engagement-enrolling the quiet majority. Organizational Development Journal 25: 171-175.

Cropanzano, R. \& Mitchell, M. S. 2005. Social exchange theory: An interdisciplinary review. Journal of Management 31(6): 874-900.

Dale-Olsen, H. 2006. Wages, fringe benefits and worker turnover. Labour Economics 13(1): 87-105.

Dielman, M., Cuong, P., Anh, L. \& Martineau, T. 2003.Identifying factors for job motivation of rural health workers in North Vietnam. Human Resources for Health 1: 1-17.

Doherty, R. 2010. Making employee engagement an end-to-end practice. Strategic HR Review 9(3): 32-37. 
Dowling, P. J. \& Welch, D. E. 2004. International Human Resource Management: Managing People in a Multinational Context. $4^{\text {th }}$ edition. Mason, Ohio: South-Western Thomson.

Economic Planning Unit. 2010. Ninth Malaysia Plan 2006-2010. Putrajaya: Prime Minister Department.

Emerson, R. M. 1976. Social exchange theory. Annual Review of Sociology 2: 335-362.

Federation of Malaysian Manufacturers. FMM Directory of Malaysian Industries 2012. 43 ${ }^{\text {rd }}$ edition. Petaling Jaya: Percetakan Okid Sdn. Bhd.

Ferris, G. R., Hochwarter, B. A., Ronald, B.M., Harrell-Cook, G. \& Frink, D.D. 1999. Human resource management: Some new directions. Journal of Management 25(3): 385-415.

Floyd, S. W. \& Wooldridge, B. 1994. Dinosaurs of dynamos? Recognizing middle managers strategic role. Academy of Management Executive 8(4): 47-57.

Frank, F. D., Finnegan, R. P. \& Taylor, C. R. 2004. The race for talent: Retaining and engaging workers in the $21^{\text {st }}$ century. Human Resource Planning 27(3): 12-25.

Gottlied, H. 2011. Benefit wizard: Engages and guides. Benefits Magazine 39: 32-43.

Gratton, L. 2004. More than money. People Management 29: 33-48.

Gubman, E. 2004. From engagement to passion for work: The search for the missing person. Human Research Planning 14(2): $42-46$

Guest, D. \& Peccei, R. 2001. Partnership at work: mutuality and the balance of advantage. British Journal of Industrial Relations 39(2): 207-236.

Hackman, R. J. \& Oldham, G. R. 1975. Development of the job diagnostic survey. Journal of Applied Psychology 60: 159-170.

Heneman, H. G. III. \& Schwab, D. P. 1985. Pay satisfaction: Its multidimensional nature and measurement. International Journal of Psychology 20: 129-141.

Herzberg, F., Mausner, B. \& Snyderman, B. 1959. The Motivation to Work. New York: John Wiley\& Sons.

Kahn, W. A. 1990. Psychological conditions of personal engagement and disengagement at work. Academy of Management Journal 33(2): 692-724.

Kaye, B. \& Jordan-Evans, S. 2003. Engaging talent. Executive Excellence 20(8): 11.

Keaveney, S. M. 1995. Customer switching behavior in service industries: An exploratory study. Journal of Marketing 59: 71-82.

Keller, J. 1999. Motivational systems. In Handbook of Human Performance Technology, edited by H. D. Stolovitch \& E. J. Kepps, 373-394. San Francisco: Jossey-Bass Pfeiffer.

Latham, G. P. \& Ernst, C. 2006. Keys to motivating tomorrow's workforce. Human Resource Management Review 16: 181-98.

Lawler, E. E. 1971. Pay and Organizational Effectiveness: A Psychological View. New York: McGraw-Hill.

Lim, J. W. L. \& Ling, Y. Y. F. 2012. Human resource practices of contractors that lead to job satisfaction of professional staff. Engineering, Construction and Architectural Management 19(1): 101-118.

Lockwood, N. R. 2007.Leveraging employee engagement for competitive advantage: HR'sstrategic role. HR Magazine March: 14-18.

London, H. \& Higgot, K. 1997.An employee reward and recognition. The TQM Magazine 9(5): 328-335.

Lucero, M. A. 1991. Employee Affective Responses to Health Insurance Benefits. Houston: University of Houston.
Markos, S. \& Sridevi, M. S. 2010. Employee engagement: The key to improving performance. International Journal of Business and Management 5(12): 89-96.

McPhie, N. A. G. 2008. The power of federal employee engagement. A Report by the U.S. Merit Systems Protection Board.

Minbaeva, D. B. 2008. HRM practices affecting intrinsic and extrinsic motivation of knowledge receivers and their effect on intra-MNC knowledge transfer. International Business Review 17: 703-713.

Mondy, R. W. 2011. Human Resource Management. $12^{\text {th }}$ edition. Boston: Pearson-Prentice Hall.

Morgan, L. 2004. Driving performance and retention through employee engagement. The Corporate Leadership Council: Engagement Survey and Analysis Tool (CLCESAT). Available at http://www.mckpeople.com.au/SiteMedia/ w3svc161/Uploads/Documents/760af459-93b3-43c7b52a-2a74e984c1a0.pdf

Omolayo, B. \& Owolabi, A. B. 2007. Monetary reward: A predictor of employees' commitment to medium scale organizations in Nigeria. Bangladesh e-Journal of Sociology 4(1): 25-38.

Palomo, M. 2004. Development and validation of a questionnaire measure of the supervisory relationship. Unpublished Doctoral Thesis. Oxford University.

Perrin, T. 2009. Employee Engagement Underpins Business Transformation. New York, NY: Towers Perrin HR Services.

Richman, A. 2006. Everyone wants an engaged workforce, how can you create it? Workspan 49(1): 36-39.

Robinson, D., Perryman, S. \& Hayday, S. 2004. The drivers of employee engagement. IES Report 408. Available at http:// www.employment-studies.co.uk/pubs/summary

Rose, M. 1998. Performance-Related Pay in Schools: An Assessment of the Green Papers. London: London School of Economics and Political Science.

Saks, A. M. 2006. Antecedents and consequences of employee engagement. Journal of Managerial Psychology 21(7): 600-619.

Sanjeevkumar, V. 2012. A Study on employees' OCB in public companies in Kedah, Malaysia. International Journal Business Economics and Management Research 2(4): 91-101.

Sardar, S., Abdul Rehman, C. H., Yousaf, U. \& Aijaz, A. 2011. Impact of HR practices on employee engagement in banking sector of Pakistan. Interdisciplinary Journal of Contemporary Research in Business 2(9): 378-389.

Scarlett, K. 2009. What is engagement? Scarlett Survey International. Available at http://wwww.scarlettsurveys. com

Schaufeli, W. B. \& Bakker, A. B. 2004. Job demands, job resources, and their relationship with burnout and engagement: A multi-sample study. Journal of Organizational Behavior 25(1): 293-315.

Sekaran, U. 2003. Research Methods for Business: A Skill Building Approach. $4^{\text {th }}$ edition. Chichester: John Wiley.

Shamsudin, F., Subramaniam, C. \& Ibrahim, H. 2011. Investigating the influence of human resource practices on deviant behavior at work. International Journal of Trade, Economics, and Finance 2(6): 514-519.

Shaw, K. 2005. An engagement strategy process for communicators. Strategic Communication Management 9(3): 26-29. 
Shuck, M. B., Rocco, T. S. \& Albornoz, C. A. 2011. Exploring employee engagement from the employee perspective: Implications for HRD. Journal of European Industrial Training 35(4): 300-325.

Silverman, M. 2004. Non-Financial Recognition: The Most Effective of Rewards. Brighton: Institute of Employment Studies.

Snape, E. \& Redman, T. 2010. HRM practices, organizational citizenship behavior, and performance: A multi-level analysis. Journal of Management Studies 47(7): 12191247.

Storey, J. 1995. Human Resource Management: A Critical Text. London: Routledge.

Subramaniam, C., Shamsudin, F. \& Ibrahim, H. 2011. Linking human resource practices and organizational performance: Evidence from small and medium organizations in Malaysia. Jurnal Pengurusan 32: 27-37.

Swindall, C. 2007. Engaged Leadership: Building a Culture to Overcome Employee Disengagement. Hoboken, N. J.: John Wiley \& Sons.

Tomlinson, G. 2010. Building a culture of high employee engagement. Strategic HR Review 9(3): 25-31.

Towers Watson. 2012. Global workforce study. Available at http://towerswatson.com/assets/pdf/2012-Towers-WatsonGlobal-Workforce-Study.pdf

Truss, C., Soane, E., Edwards, C., Wisdom, K., Croll, A. \& Burnett, J. 2006. Working life: Employee Attitudes and Engagement 2006. London: Chartered Institute of Personnel and Development.

Vance, R. J. 2006. Employee Engagement and Commitment: A Guide to Understanding, Measuring and Increasing Engagement in Your Organization. Alexandria: SHRM Foundation.

Weiss, D. J., Dawis, R. V., England, G. W. \& Lofquist, L. H. 1967. Manual for the Minnesota Satisfaction Questionnaire. Minneapolis: University of Minnesota.

Wagner, R. \& Harter, J. K. 2006. The Element of Great Managing. Washington: Gallup Press.

Wellins, R. S., Bernthal, P. \& Phelps, M. 2005. Employee engagement: The key to realizing competitive advantage. Development Dimensions International. Available at http://www.wip. ddiworld.com/pdf/ddi employeeengagement_mg.pdf

Werner, J. M. \&DeSimone, R. L. 2009. Human Resource Development. International Student Edition. $5^{\text {th }}$ edition. South-Western College Pub: Thomson Learning.

Wilkinson, A. 2007.Employee engagement. Available at http:// employeebenefits.co.uk/item/2663

Johanim Johari (corresponding author)

School of Business Management

College of Business, Universiti Utara Malaysia

06010 Sintok, Kedah, Malaysia

E-Mail: johanim@uum.edu.my

Zurina Adnan

School of Business Management

College of Business, Universiti Utara Malaysia

06010 Sintok, Kedah, Malaysia

E-Mail: rina@uum.edu.my

Tan Fee Yean

School of Business Management

College of Business, Universiti Utara Malaysia 06010 Sintok, Kedah, Malaysia

E-Mail: feeyean@uum.edu.my

Khulida KiranaYahya

School of Business Management

College of Business, Universiti Utara Malaysia

06010 Sintok, Kedah, Malaysia

E-Mail:khulida@uum.edu.my

Site Nora Isa

School of Business Management

College of Business, Universiti Utara Malaysia

06010 Sintok, Kedah, Malaysia

E-Mail: stnisa@yahoo.com 